\section{Research Article}

(C) 2021 Perskaya et al. This is an open access article licensed under the Creative Commons Attribution-NonCommercial 4.o International License (https://creativecommons.org/licenses/by-nc/4.o/)

Received: 15 July 2021 / Accepted: 12 October 2021 / Published: 5 November 2021

\title{
The COVID-2o19 Pandemic as a Catalyst of the Potential Loss of Democratic Foundations of Society's Social Life
}

\author{
Victoria Vadimovna Perskaya ${ }^{1}$ \\ Valery Leonidovich Abramov ${ }^{2}$ \\ Victor Yakovlevich Pishchik ${ }^{3}$ \\ Peter Viktorovich Alekseev ${ }^{4}$ \\ Marina Borisovna Medvedeva 5 \\ Lyubov Igorevna Khomyakova ${ }^{6}$
}

${ }^{1}$ Professor, Dr.Sc. (Economics), Director,

The Institute for Research of International Economic Relations,

The Financial University, Moscow, Russia

${ }^{2}$ Professor, Financial University under the Government of the Russian Federation,Moscow, Russia ${ }^{3}$ Professor, Dr. Sc. (Economics), Department of Global Finance,

Financial University under the Government of the Russian Federation, Moscow, Russia

${ }^{4}$ Leading Researcher, Ph.D. (Economics), Institute of Global Economy and International Finance, Financial University under the Government of the Russian Federation, Moscow, Russia

5 Professor, Department of Global Finance,

Financial University under the Government of the Russian Federation, Moscow, Russia

${ }^{6}$ PhD, Lead Research Fellow, The Institute for Research of International Economic Relations,

Financial University under the Government of the Russian Federation, Moscow, Russia

DOI: https://doi.org/10.36941/ajis-2021-0171

\section{Abstract}

The pandemic-2020 has come quite unexpectedly despite the repeated warnings from WHO. It turned out that the infection's spread in all countries of the world and the new-how to resist it depends on the ability to mobilize national system of health protection. So, on the quality of the provided medical service, on the accessibility to all levels of the society and on the ability of countries' governments to provide with proper regulation of social life self-isolation, on-line work and quarantine regimes became the most effective tools in the world. It demanded the appropriate control mostly based on new technological solutions. Remote work and the possibilities of modern technologies to track and identify people may get elaboration after the end of the pandemic-2020. There is a great possibility to lose a part of democratic freedom of society due to using new systems of social life control in order to increase countries functioning effectiveness as the main units of a polycentric model of the world order. It is emphasized that polycentrism should lead neither to the totalitarianism of power nor to the loss of democratization of social life. The government should promote this process by increasing the effectiveness of its activity not substituting it for total control based on ICT.

Keywords: Pandemic; on-line work; self-isolation, systems of tracing and control, based on ICT, democratic rights and freedoms, polycentrism 


\section{Introduction}

A specificity of a modern stage of international community means that all countries (economically, mentally and socially) are integrated quite deeply because of the development of globalization process. The level of mutual dependence of countries, including the development of global value chains and accepted ideology of post-industrialism for developed countries, formed a basis for actual loss of stability by national economies. More than that, they became incapable to provide security to nations on a national scale. As Wright N. (Wright 2020) notes the longer the pandemic goes on, the more the world changes. A real risk is that long lasting crisis influences on the international cooperation destructively, first between western allies of the U. S. and between America and China.

In 2019 the World Health Organization (WHO) published a manual about a possible reaction on the pandemic. Preventively, it is offered to decrease the influence of seasonal influenza, to strengthen control and to minimize a risk of the development of "zoonotic diseases" mainly of influenza group and to organize the preparation on softening the influence of the pandemic flu (World Health Organization 2019). Practically, not a single big country perceived those recommendations seriously, unless Russia that took actions for mass coverage by vaccination from seasonal flu starting the campaign on September 4, 2019 (Wright 2020).

All other countries, de facto, did things they thought necessary to provide their interests not burdening a multitude of existent problems by questions in cooperation with other countries in the field of health protection (Wright 2020).

Thus, a real agreement of countries' reaction of international community on the pandemic COVID-2019 is shown in disconnection of actions, in opposition of national egoism to the possibility of coordination and in agreement of countries' measures to speed up the liquidation of mass infection of population.

It makes sense to suppose that the level of sickness rate in a greater degree depends on the ability to mobilize the systems of health protection in countries, on the controllability of social life by societies. Consequently, it is important for societies to have charismatic, competent and strong leaders who have an ability to provide the stability of development, security and social health of nation.

The main process of transformation in the international community on the way to the polycentric organization (Channel One Russia 2020; AIF-Tver 2020) logically supposes the rising of the government role, itself as the main actor of the international relations. In its turn, it requires the increase of effective work from the government. Taking part into the person's psychology, the most essential tools will be those that are the most available and already exist. These tools will naturally clash with democratic foundations of public life formed during the liberal international order.

\section{Methods}

Methodology of comparative analysis and comparisons is allowed to make a conclusion that the pandemic-2020 put to the fore the provision of national security and people's health, as tasks of the government. Isolation and remote work became the instruments of universal prevention.

The analysis of advantages and disadvantages of remote work and mechanisms of control the isolation in different countries in the world is allowed to make a conclusion that restriction of personal liberties in extreme conditions was well founded. The tools to control may be maintained in conditions of "peaceful life", based on new technologies and mobilization of the potential of artificial intelligence. The strengthening of regulating influence of the government on society is provided in order to supply with social security and order.

The study of theoretical positions to transfer to polycentrism was permitted to formulate proposals and recommendations to maintain, unconditionally, democratic structure of the government and public life in order to prevent the spread of totalitarianism and usurpation of the power by charismatic leaders, de facto, was required by logic of development of the world community 
and societies. The pandemic-2020 has shown practically the necessity to be at the head of the process of confrontation the epidemic from the very beginning. For example, the President Trump D. speaks every day announcing measures of fight, but public activities of the U. S. blame him for not becoming autocrat earlier (P. J. Buchanan 2020).

This study focuses on the ability of the ruling elites of the states of the world in conditions of real polycentrism to use effective tools of control and management of society in the post-pandemic era, which are actively used during the epidemic. The factor of such behavior of the elites is the implementation, first of all, at the educational level (from school to university) of the principles of reasonable democratic development, education of individuals in the spirit of tolerance, and preservation of human diversity, respect for a person as a person and steady growth of his spiritual component.

\section{Literature Review}

The questions for development of the democratic foundations of social development (Alberdi Bidaguren 2016) are observed in the context of changes as in the society itself and the organization of occupation. At the context of enlargement rights and opportunities that themselves can be both positive and negative for human development, including actions to strengthen institutions and forms of cooperation between subjects of community and to provide balance of interests between the trade market and government.

At the same time, legitimacy of political actions depends on realization of justice concept where the decisive factor is democracy (Dubois 2015). There is a fundamental approach on evaluation the role and essence of the concept democratic society as a society where the government relies on freely agreed consensus of leaders' and the government's interests (Hook 1939). The issue of interrelationship of society development, including the use of the Information and Communications Technology (ICT)and preservation the democratic foundations of social organization is observed in the materials of the World Bank Group with reference to the African continent (for example, see Sikuka [2017]). The preservation and development of democratic foundations of social life are directly corresponded with a modern trend of strengthening the regulative and controlling functions with the help of ICT from employers and state apparatus. There is avoiding totalitarianism in developing economies and taking into account that individual political behavior of citizens is mostly formed by the past of a person (Petrović, van Stekelenburg and Klandermans 2014).

\section{Results and Discussion}

\subsection{Remote work}

The main tool to avoid the spread of virus infection has become stoppage of contacts between people in cities and in countryside. It was a catalyst to activate the use of ICT to communicate, do the shopping and deliver goods, to use robots in infectious hospitals and to provide control for citizens' movements.

The switch of workers to remote work (from home) required introduction of new Internet access systems that are faster and have high-data-rate while doing the full volume of tasks. Moreover, the level of the Internet networks expansion should, in fact, include all regions of the world society. At the same time, the remote work means that workers should have resources to fulfill their job. The challenges for universities in the period and after the pandemic are the academic mobility reduction, the weakening of partnerships necessary for the development of new master's programs, new research projects in which master students can participate, other challenges (EAIE, 2020; EUA, 2020; Inside HE Ed; QS, 2020a; HSE, 2020). In that way, the demand for means of communication through the Internet should grow in all countries. According to Microsoft, the pandemic COVID-2019 will become an important turning point and it will change the formats of work and education forever - 
said the HoD of Microsoft 365 Spataro J. ... In March 2020 the demand for corporate messenger, Microsoft Teams (Microsoft 365) increased all over the world. The number of everyday users grew from 32 million to 44 million only for one week. The demand for computers and laptops is also increased, as iPad does not suit to work from home. The preservation of the trend to remote work can remain after the end of the pandemic. Microsoft fixes the double growth of users of Teams messenger after canceling the quarantine in China (Lipanova 2020).

According to the Brookings institute, at present, about $1 / 2$ of American workers work from home. It is more than twice the number of people working from home in 2017-2018 (Guyot and Sawhill 2020). The pandemic is provoked to speed up the move to the remote work. It will probably be a long-term tendency not only in the U. S., but also in the world. Previously, the employers took that kind of work a little bit skeptically, though

technologies themselves had been already developed. The inertness of employers' perception reflects a stereotype of traditional work culture and lack of interest from employers to invest the technologies and methods of management that are necessary to supply working process on the remote resource.

The pandemic forces to realize these investments in the spheres where the work based on ICT is possible. There are some positive aspects of remote work. The workers stay home and it reduces expenses on transportation, city infrastructure, expenses on maintaining offices. Remote work helps people (especially women) to combine work and family responsibilities. As rule, highly paid specialists can mainly work remotely. At a growth rate of remote work for 2-3 percent per year the segment was the most fast growing in the U. S. for the last few years (Guyot and Sawhill 2020).

Accordingly, we should suppose that new culture of remote communication would take its place after the pandemic.

However, remote work has disadvantages.

The first, there are difficulties to control workers from the part of middle managers that require new methods to control workers.

The second, professional isolation can have negative consequences on mind, well-being and career development of employees and, finally, the growth of labor productivity can hardly take place in long-term perspective.

Thirdly, a great number of remote workers can lead to the productivity reduction, to higher number of skips, to the increase of employee turnovers among those, who do not work remotely especially if some members from collective have restricted time for personal meetings.

In addition, the last negative effect is that, in fact, for employers remote work makes a person invisible to progress him \her up career ladder. Managers perceive workers who are in the office better because average managers are inclined to think that workers are less productive working from home in comparison with those in the office because remote work reduces people's concentration, motivation and productivity, as they are not controlled.

Experts point that the increase of productivity is not guaranteed in the conditions of complication to control staff productivity. For instance, in the U. S. Yahoo and Reddit publicly rejected the remote work because of that. It is necessary to have a recurring social contact with the staff for success of creative approach at work. Creative groups are much more effective when communication is real, but not virtual. However, working out of the office focuses better on individual tasks. Social interaction at work is important for morale of workers and staff overall. In this connection, it is quite likely that after the pandemic remote work ("udalyenka") will be a reality including attraction of workers from remote regions. It will be quite a popular form to attract staff, including mall-scale business enterprises.

According to the polls of the international association of universities, the challenges for the activities of universities during the pandemic were: suspension of educational activities - typical of $24 \%$ of respondents; a decrease in the number of applicants - for $46 \%$, inability to complete scientific research on time $-52 \%$ weakening of partnerships took place for $59 \%$ of respondents, and a decrease in academic mobility became the most serious factor for $89 \%$ of respondents (Moscow, 2020). 


\subsection{Systems of controlling and monitoring society}

In today's conditions, systems of controlling society are widely used based on mobile phones that are widely used in the conditions of the pandemic-2020. In fact, the mobile phones industry became a base to create a global system of data exchange that can track people all over the world in the framework of the policy to control the spread of the COVID-19 (Kirchgaener2020).

Until recently, national governments have restricted the use of mobile phones as a tool of tracking the movements of citizens. It either present monitoring of data within their borders or discuss it with the mobile operators and technological companies. In the modern world of the COVID pandemic, it has its place in the U. S., India, Iran, Poland, Singapore, Israel and South Korea (Kirchgaessner 2020). The idea of international system of mobile tracking will be evidently enlarged in the conditions of the pandemic. It will enable governments to track movements and to control the spread of the disease through borders potentially. GSMA represents the interests of more than 750 operators and suppliers of mobile phones in the world and contributes the developing of international standards (GSMA 2020). The goal of such a global network would be the introducing "contacts tracking" that enables governments to use location data of a mobile device in order to see with whom an infected COVID-19 person could contact.

However, the pandemic is ending, but the system remains and it will require means and efforts for its existence. For all that, the system of control is side by side with possible desire to regulate behavior of society's members and not at all in the interests of a country development being at a great distance from citizens who are an object of control.

For instance, there are negotiations with Facebook, Google and other technical companies and experts in the sphere of health protection to use data about a person's location via mobile phone to fight against the pandemic in the U. S. There is a level, that allows the government to track people who are suspected or confirmed to be infected; it informs people, who may have connected with them in Israel. Their mobile phones are also under control of strict rules of the quarantine. The British are concerned using their personal information and demand to protect data privacy as the schemes of using the information are not transparent and it is not known how they will be used in future.

Hangzhou, (China, headquarters of Alibaba) was the first who used large data and information technologies to prevent the spread of the COVID-2019 and control rules of isolation. They called the approach "one card, one QR-code and one index" (Wu, Xu, and Wang 2020). They developed codes of health that were realized everywhere in China (it should be noted that analogically there were introduced permits on the entrance to Moscow and regions of Russia based on QR-codes). China mobilized the resources, that had to mass observation (from drones to surveillance cameras) to monitor people on quarantine and track the spread of coronavirus. Thus, private companies started to develop new platforms that could be used in the framework of the social system credit later. A few countries (Israel, Singapore and South Korea) resorted to experience of China and started to use a combination of data location, video from cameras and information on a credit card to track COVID19 in their countries (Kharpal 2020).

There are the set surveillance cameras by the government in China that show apartments' door of those who are on 14 days quarantine in order to guarantee their staying at home. The arrangement of equipment was arranged without the residents' agreement. Drones inform about the necessity to wear masks through loudspeakers and digital bar codes on mobile phones' applications reflect people's health.

However, how much is confidentiality of cumulative data gathered by all services guarantied? In addition, how long will the gathered information be stored after the end of regime of increased level of the epidemiological surveillance? We think there is fully justified experts' position of Human Rights Watch on necessity to work out rules and norms in society to provide social agreement in using such systems in ordinary times (Kharpal 2020).

Israel agency of security Shin Bet uses location data of citizens' mobile phones to trace where 
they have been in order to control quarantine and trace movements of infected people.

The period of collecting data on citizens and how much this "information society" provides democratic rights and freedoms of citizens, becomes a natural question.

At the same time according to Electronic Frontier Foundation (EFF), non-commercial group on protecting digital confidentiality, data collection is based on mobiles location. It is not proved its effectiveness on tracing the virus spread as "new governmental authorities on controlling location, de facto, it is a threat for our digital rights" because global position control system (GPS) on smartphones has a precision only up to a sixteen-foot radius (GPS 2020).

The data gathering system and data processing of all citizens of a country is certainly a step to future and the use of artificial intelligence to process these data too but regulation of social and public surrounding based on them is already a step to lose democratization of public life.

Government institutions which use these tools to increase effectiveness of their activity in conditions of enhancement of the government role in conditions of the pandemic COVID-19 will hardly agree to lose the possibility of controlling and managing society's life, especially in conditions of reorganization the world to polycentrism.

Kahn Albert F. (an executive director of the control project for technologies of video monitoring in uncommercial advocate group) has noted the fact that there is a precedent to prolong the periods of data processing in American practice, if it is in the interests of the ruling elites.

In this connection, the pandemic-2020 raised a question of securing society in social and public environment, saving a balance between necessity to use technologies and data for the welfare of society and confidentiality protection.

The process of democratizing education in a pandemic has also found itself in a kind of systemic crisis. This is because the process of socialization of applicants and inclusiveness, tolerance of perception of the opinion and lifestyle of other people is disrupted. In the distance mode, the student's "ego" develops excessively, the importance of self-preparation increases with a significant increase in the workload of teachers. The pandemic has had a significant impact on the plans of potential foreign students to study abroad, disrupting the process of internationalization of education, which has spread in recent decades. International students have postponed university admissions until after the pandemic. Universities have become compelled to train teachers to work with international students in a digital environment. But there are positive aspects: intensive work on the formation of new formats of interaction with partners, the development of crisis plans together with partner organizations, an increase in virtual mobility and a strengthening of the third role of universities.

The most successful countries have set up foundations and hotlines to help students. The most successful universities, in addition to using modern approaches to online education, have created an online community of students, teachers, and administrators, which contributed to improving the quality of education and reducing the stress of social isolation.

\subsection{Polycentrism, democratization and artificial intelligence}

Great Britain was one of the first who offered to use apps that as if did not violate democratic and personal liberties of people. They promoted the app to countries with centralized health care system. In contrast with a system of controlling smartphones in China, the British project will completely rely on free-will participation and sense of civic responsibility. The system could glean detailed location data from a variety of sources, including Bluetooth beacons, nearby Wi-Fi networks, GPS and cell towers.

All these attempts evidence, that countries with traditionally developed democracy aim to find out technological and technical solutions by utilization the AI abilities and not to break democratic foundations of social life.

The transition of the world community to polycentrism/multi polarity was regarded in our works in its different constituents. In this context, we consider important to notify the position of 
Savin L. (2018), who emphasizes that polycentrism means the existence of centers in the context of the international policy. It is a government (or a group of governments) that is a sovereign actor in the international relations. The idea of multi polarity was included in the concept of foreign policy of Russia and its founder is Primakov E. M. (Kortunov 2019).

Several researches consider that... This unipolar structure has been just a predecessor of multi polar structure that appears nowadays. Multi polar structure is based on principals of self-sufficiency, independence, openness and predictability (E. Buchanan 2019)

Accordingly, the government role in the national development regulation should be restored contrary to the doctrine of international and liberal order, which promotes the ideology of lowering the government role.

In its turn, these means will be actively used by administrative units of all countries in modern conditions of development of the artificial intelligence (AI), information and communication technologies as means of tracking, controlling and governing. In this connection, we think that the article of Kissinger H. (2020) is remarkable. He points out the necessity of an effective government to overcome unprecedented challenges in scale and global nature. There is a need to preserve social faith for social solidarity. It is necessary to maintain good relations between societies and to have stability in the world because "the damage to the social health will be temporal, but political and economic chaos can be delayed for generations caused by this virus" (Kissinger 2020).

It seems to us that Mr. Kissinger's idea concerning the government concept, based on the law is also important. It is aimed to satisfy fundamental needs of population: to give safety, order, economic prosperity and legal guarantees. Persons cannot provide all these benefits without the government. At the same time, it should not be inclined to the rejection from "social agreement" ("social contract" - a term of philosophers of the Age of the Enlightenment) that can be torn up as inside the U. S. so in the scale of the international community (Kissinger 2020).

Some experts (Bosco 2020; Green and Medeiros 2020) consider that "social trust" and "social solidarity" are, in fact, an effective government strategy to connect with society, including the use of false news and double standards.

It is a social support of elitist projects" such as globalization, opening borders and free capital movement. These principals, de facto, do not take into account "interests of working people who are considered to be silly mules. Kissnnger wants to keep this world order in American and centric empires ruled by elites of the establishment - dribbling plutocrat and bank mafia" (Whitney 2020).

Fukuyama F. (2018) emphasizes that a society should protect not only marginal and small groups who identify themselves as joined by certain beliefs, characteristics or values, but on the whole ensure existence consensus and common aims of development. A shift toward narrow group identity protection threatens the development at the end.

Historically, a struggle between authoritarianism, protectionism, protection of national interests and liberalism, free-trade and concessions of national interests and subjection them to global values took place in Russia as a special case from $18-19^{\text {th }}$ centuries. The Russian scientist Mendeleev D. I. pointed out that

... except the primary protectionism willing to develop everything in the country, and not to admit foreign goods that can be produced in the country and besides protective protectionism we exist and think... excitatory reasonable protectionism that imposes high customs duties on goods that have all chances to develop them inside country taking into consideration all natural conditions of the country. (Berlin1925)

In this regard, we believe, that it is possible to consider a reasonable democracy as a deterrent a tool to progressive authoritarianism. It does not meet national interests and proclaims the destruction of certain nations to prosperity and welfare of other nations, based on despotism and hatred of humanity under power usurpation and a cult of personality proclamation carried out by supporters of a charismatic leader. It does not exclude the role of charismatic leader in the government development overall, but at the same time it inputs restraining restrictions for authoritarian progress and development of a cult of personality. 
A reasonable democracy is a system that does not overemphasize and does not bring democratic principles to absolutism and absurdity allowing a society to develop and to reproduce itself.

A reasonable democracy is against the so-called radical supporters of democracy when they start to act against the preservation of humanity principles and, de facto, destroy a society.

A reasonable democracy should be based on strong institutions of the country and support the development of an active civil society. Nowadays it is provided by the development of social networks and the Internet.

In this article we can only schematically point out the main parameters (as it is not a subject of the research) that are able to restrain authoritarianism of the state power in the framework of social and liberal attitude of the government to aims and tasks of comprehensive society development and raising the country's population standard of living. They are electivity of the first rulers of countries, which means generality of national election; transparency of voting, video and digital control over them not admitting anonymous digital voting, etc. There is freedom constitutional consolidation, to express thoughts and will of all citizens; independence of judicial system from state power and electivity of judges; civil servants rotation (every five years) when passing qualification exams excluding clanship or nepotism within government apparatus, including regional and local levels. The development of civil society by forming movements and platforms assists the development of social and oriented projects. The ways of consolidation of social groups in assistance with the development of creative potentials and interests; arranging open processions and demonstrations in different cities and regions devoted to important events of peoples' development and their history; public discussions of legislative initiatives using the Internet resources and social networks as a form to control social interests. Along with them, it is a resistance of the society division into stratum, groups and subgroups that sometimes perceive each other antagonistically or marginally because of their aggressive imposition of controversial ideals from the generally accepted morality. All they thoroughly check sources of finances to develop non-formalized movements of civil society, excluding the use of means from unsettled foreign sources. In other words, the development of civil society should be subordinated to the aims of society consolidation for constructive aims of development and social help to the destitute and unprotected groups resisting the ideas of destruction and antagonism.

Being an instrument of realization, the national interests of multinational and mono ethnic countries the government should consolidate all groups of society in their activity and contribute preservation of historical memory and historical pride, forming the atmosphere of freedom to realize citizens personal potentials and their identification in civil society. At the same time, it should direct its activity as an institution of control on the comprehensive increase of the citizens welfare level and the mission of protection the territory and social support of the country's population.

These are general restrictions for not admitting, "Authoritarian's prosperity" in the conditions of strengthening the government role when transferring to multi polarity. These restrictors should contribute to combination of authoritarian power of a charismatic elected first person and the development of social and political public system liberalization.

\section{Conclusion}

In the pandemic-2020 epoch some measures apply strong restrictions on people's freedom including their private life and other people's rights. Unprecedented levels of control using large databases and checking disinformation are used in all countries in the world. Many measures are based on extreme government powers; others use exceptions in data protection laws for their exchange. Some tools may be effective and may be based on recommendations of epidemiologists, others may be not. However, all these mechanisms including activation to attract potential of AI should be temporal and proportional to threats and challenges (Privacy International 2020), necessary in modern conditions, but they should not be extended during "the post-coronavirus" world order. And, of course, a 
significant role in ensuring the preservation of the democratic foundations of social life belongs to the education system, where not only knowledge is given, but the process of forming a personality is underway, defining his rights about responsibilities in the context of the development of democracy in public life.

\section{References}

AIF-Tver. 2020. "Mir Posle Pandemii. Politolog Rami Al'-Shayer - o Missii Rossii [The World after the Pandemic. Political Scientist Rami Al-Shaer: On Russia's Mission].” Arguments and Facts (Tver), No. 18, April 28. https://tver.aif.ru/politic/mir_posle_pandemii_politolog_rami_al-shaer_o_missii_rossii.

Alberdi Bidaguren, Jokin. 2016. The Political Dimension of Local Human Development: Key Points for the Construction of Alternatives and Cohesive Societies. Vol. 1. Bilbao: HEGOA. http://publicaciones.hegoa.ehu.es/es/publications/386.

Berlin, P.A. 1925. Russkaya burzhuaziya $v$ staroye i novoye vremya [The Russian Bourgeoisie in the Old and New Times]. 2nd ed. Moscow, Leningrad: Publishing house "Book."

Bloom, Nicholas, James Liang, John Roberts, and Zhichun Jenny Ying. 2015. "Does Working from Home Work? Evidence from a Chinese Experiment." The Quarterly Journal of Economics 130 (1): 165-218. doi:10.1093/qje/qjuo32.

Bosco, Joseph. 2020. "Kissinger's Post-Pandemic World Order and the Demise of the Chinese Communist Party." Text. The Hill. https://thehill.com/opinion/international/491777-kissingers-post-pandemic-world-orderand-the-demise-of-the-chinese.

Buchanan, Elizabeth. 2019. "What Russia Wants in a Multi polar World." The Interpreter. https://www.lowyinstitute.org/the-interpreter/what-russia-wants-multipolar-world.

Buchanan, Patrick J. 2020. "Kissinger's Call for a New World Order." The World. https://theworldlink.com/opinion/columnists/kissingers-call-for-a-new-world-order/article_3b552eoc7948-11ea-ae88-8b26f4f21594.html.

Channel One Russia. 2020. "Otvety S. Lavrova v programme 'Bol'shaya igra na "Pervom kanale", Moskva, 25 aprelya 2020 goda [Answers of Sergey Lavrov in the program " 'The Big Game' on the Channel One Russia, Moscow, April 25, 2020.” E-News.su. https://e-news.su/mnenie-i-analitika/329572-otvety-slavrova-vprogramme-bolshaya-igra-na-pervom-kanale-moskva-25-aprelya-2020-goda.html.

Dubois, Alfonso. 2015. Local Human Development's: Theoretical and Methodological Framework. Bilbao: HEGOA. http://publicaciones.hegoa.ehu.es/eu/publications/342.

Fukuyama, Francis. 2018. "Against Identity Politics: The New Tribalism and the Crisis of Democracy." Foreign Affairs, August 14. http://viet-studies.net/kinhte/Fukuyama_Against Identity Politics.pdf.

GPS. 2020. "What Is the Government's Commitment to GPS Accuracy?" GPS.gov - Official U.S. government information about the Global Positioning System (GPS) and related topics. https://www.gps.gov/systems/gps/performance/accuracy/.

Green, Michael, and Evan S. Medeiros. 2020. "The Pandemic Won't Make China the World's Leader: Few Countries Are Buying the Model or the Message From Beijing." Foreign Affairs, May 7. https://www.foreignaffairs.com/articles/united-states/2020-04-15/pandemic-wont-make-china-worldsleader.

GSMA. 2020. "Who We Are." In GSMA Membership: Discover the Benefits of Membership. London, UK: GSMA. https://www.gsma.com/membership/wp-content/uploads/2017/o2/Membership-Brochure.pdf.

Guyot, Katherine, and Isabel V. Sawhill. 2020. "Telecommuting Will Likely Continue Long after the Pandemic." Brookings. https://www.brookings.edu/blog/up-front/2020/o4/o6/telecommuting-will-likely-continuelong-after-the-pandemic/.

Hook, Sidney. 1939. "Democracy as a Way of Life." In Tomorrow in the Making, edited by John N. Andrews and Carl A. Marsden, 31-46. New York: Whittlesey House. https://www.mtholyoke.edu/acad/intrel/interwar/hook.htm.

Kharpal, Arjun. 2020. "Use of Surveillance to Fight Coronavirus Raises Concerns about Government Power after Pandemic Ends." CNBC. https://www.cnbc.com/2020/o3/27/coronavirus-surveillance-used-by-governments-tofight-pandemic-privacy-concerns.html.

Kirchgaessner, Stephanie. 2020. "Mobile Phone Industry Explores Worldwide Tracking of Users." The Guardian, March 25. https://www.theguardian.com/world/2020/mar/25/mobile-phone-industry-explores-worldwidetracking-of-users-coronavirus.

Kiselev, Dmitry. 2020. "Coronavirus uskoril nastupleniye budushchego [Coronavirus accelerated the onset of the future].” Vesti.ru: News of the Week. https://www.vesti.ru/doc.html?id=3254343. 
Kissinger, Henry A. 2020. "The Coronavirus Pandemic Will Forever Alter the World Order: The U.S. Must Protect Its Citizens from Disease While Starting the Urgent Work of Planning for a New Epoch.” The Wall Street Journal, April 3. https://www.wsj.com/articles/the-coronavirus-pandemic-will-forever-alter-the-worldorder-11585953005.

Kortunov, Andrey V. 2019. "Between Polycentrism and Bipolarity: On Russia's World Order Evolution Narratives." Russia in Global Affairs 17 (1): 1-35. doi:10.31278/1810-6374-2019-17-1-10-51.

Lipanova, Liana. 2020. "Microsoft sprognoziroval, chto ne vse otkazhutsya ot 'udalenki' i vernutsya v ofisy posle okonchaniya pandemii: Pandemiya Covid-19 stanet povorotnym momentom, kotoriy navsegda izmenit format raboty i obucheniya [Microsoft Forcasted That Not Everybody Would Refuse the 'Udalenka' and Would Return to Offices after the Pandemic: The Covid-19 Pandemic Will Be a Turning Point That Will Forever Change the Formats of Work and Training].” Brainity.moscow. https://www.brainity.moscow/career/news/microsoft_sprognozirovala_chto_ne_vse_otka zhutsya_ot_udalenki_i_vernutsya_v_ofisy_posle_okonchaniya_.

Ma, Alexandra. 2018. "Kak rabotayet kitayskaya sistema reytinga grazhdan: Prestupleniya i nakazaniya [How the Chinese System of Rating the Citizens Works: Crimes and Punishments]." Habr. https://habr.com/ru/post/412263/.

Petrović, Igor, Jacquelien van Stekelenburg, and Bert Klandermans. 2014. "Political Socialisation and Social Movements: Escaping the Political Past?" In The Palgrave Handbook of Global Political Psychology, edited by Paul Nesbitt-Larking, Catarina Kinnvall, Tereza Capelos, and Henk Dekker, 403-422. Palgrave Studies in Political Psychology Series. London: Palgrave Macmillan UK. doi:10.1007/978-1-137-29118-9_23.

Privacy International. 2020. “Tracking the Global Response to COVID-19." PI (Privacy International Campaigns). https://privacyinternational.org/examples/tracking-global-response-covid-19.

Savin, Leonid. 2018. "Mnogopolyarnost' i politsentrizm [Multi polarity and Polycentrism]." Geopolitika.ru. https://www.geopolitica.ru/article/mnogopolyarnost-i-policentrizm.

Sikuka, Kizito. 2017. "Is There a Link between Democracy and Development in Africa?" Conflict Trends (ACCORD), March. https://www.accord.org.za/conflict-trends/link-democracy-development-africa/.

Valentino-DeVries, Jennifer. 2020. “Translating a Surveillance Tool into a Virus Tracker for Democracies.” The New York Times. https://www.nytimes.com/2020/o3/19/us/coronavirus-location-tracking.html.

Whitney, Mike. 2020. "Henry Kissinger Calls for a New Post-Covid World Order." Global Research - Center for Research on Globalization. https://www.globalresearch.ca/henry-kissinger-calls-new-post-covid-worldorder/570880o.

World Health Organization. 2019. Global Influenza Strategy 2019-2030. Geneva: World Health Organization. https://apps.who.int/iris/bitstream/handle/10665/311184/9789241515320-eng.pdf?sequence=18\&isAllowed=y.

Wright, Nicholas. 2020. "Coronavirus and the Future of Surveillance: Democracies Must Offer an Alternative to Authoritarian Solutions." Foreign Affairs, April 6. https://www.foreignaffairs.com/articles/2020-04o6/coronavirus-and-future-surveillance.

Wu, Xifeng, Xiaolin Xu, and Xuchu Wang. 2020. "COVID-19 Response: 6 Lessons from China's Zhejiang Province and Hangzhou.” World Economic Forum. https://www.weforum.org/agenda/2020/o3/coronavirus-covid-19hangzhou-zhejiang-government-response/. 